\title{
REVIEW
}

UDC 577.112.37:577.112.6

doi: https://doi.org/10.15407/ubj93.05.005

\section{SHORT PEPTIDE SEQUENCES: CURRENT KNOWLEDGE AND FUTURE PROSPECTS}

\author{
C. M. NASADYUK \\ Danylo Halytsky Lviv National Medical University, \\ Department of Biochemistry, Lviv, Ukraine; \\ e-mail:nasadyukch@gmail.com
}

Received: 09 March 2021; Accepted: 22 September 2021

According to modern knowledge, the biological effect of many peptides is mediated by their shortchain fragments - oligopeptides - ranging from 2 to 20 amino acids and the activity of short peptides often significantly exceeds the activity of the peptide precursor. Aim of the review was to summarize the uptodate data on the stability of short peptide sequences, mechanisms of cell penetration, interaction with cell receptors, biological effects and approaches to clinical application. Stability of short peptides is mediated by their structure and molecular weight. Some di-/tripeptides were reported to be able to permeate through intestinal membranes in their intact forms via peptide transporter systems, while others are vulnerable to protease degradation. Although pinocytosis is presumed to be the main mechanism how short peptide sequences enter the cell, some lipophilic oligopeptides were shown to penetrate the cell membrane by the same mechanism as steroid or thyroid hormones and specific extracellular receptors were also described. Low-weighing oligopeptides realize their effect on the cell, chromosomal, genome and molecular levels. The advantages of oligopeptides include oral availability (for low weight compounds), low immunogenicity, high tissue specificity, faster biological effect, better cost efficiency and environmental friendliness of their synthesis. Hence, short peptide sequences are regarded as promising candidates for pharmacotherapy, cell cultures and drug delivery purposes.

Ke y w o r d s: short peptide sequence, oligopeptide, peptidergic regulation, proteomics.

$\mathrm{P}$ eptides are central to the regulation and modulation of the chemical reactions and biological responses that occur in nature [1-3]. Peptidergic regulation of homeostasis is supposed to be phylogenetically the oldest form of bioregulation [2]. Being biocompatible, biodegradable, bioactive, and relatively amenable to large-scale production, peptides are currently gaining interest as potential agents in different fields of medicine [4]. Peptide drugs have obvious advantages over the non-peptide drugs such as high activity, low toxicity since they consist of endogenous amino acids, the absence of severe side effects, and lower probability of tolerance or dependence [5].
According to modern knowledge, it is recognized that the biological activity of many peptides is mediated by their short chain fragments, oligopeptides [1-3, 5], e.g. the inhibition of pancreatic juice secretion by ghrelin is realized by the active part of the hormone with the sequence of amino acids GlySer-Ser-(n-octanoyl)-Phe [6]. And the biologically active part of thymopoietin is a pentapeptide with a structure Arg-Lys-Asp-Val-Tyr [2, 4, 7-9].

The medical potential of short sequence peptides was initially characterized many decades ago with the identification of biological mediators such as angiotensin, vasopressin, oxytocin and bradykinin [10]. The proline-rich oligopeptides described 
in venom from some kinds of snakes were the first naturally occurring angiotensin-converting enzyme inhibitors described and inspired the design of current commercial inhibitors of angiotensin-converting enzyme [11].

Oligopeptides are defined as peptide sequences ranging from 2 to 20 amino acids $[2,10]$. Numerous oligopeptides are produced in the course of limited proteolysis and their activity often significantly exceeds the activity of the peptide precursor [2]. Other advantages of oligopeptides include oral availability in contrast to polypeptides since many short sequences are resistant to the effect of gastrointestinal proteinases, low immunogenicity, especially of the compounds containing less than 8 amino acids, high tissue specificity, quicker biological effect, better cost efficiency and environmental friendliness of their synthesis $[1,2,10,12]$. To date, the chemical structures of oligopeptides from more than 2,000 organisms representing all the biological kingdoms have been identified [13].

Natural oligopeptides are considered to regulate nearly all vital processes, namely the proliferation and differentiation processes in various types of cells and tissues, protein synthesis, intracellular communication, nociception, vessel permeability, neoangiogenesis [3, 9, 14]. Thus, bioactive peptides offer a promising approach for many medical and pharmaceutical applications [1, 3, 10, 15, 16].

Purpose of the current review was to summarise modern data on the stability of short peptide sequences in plasma and gastrointestinal tract, cell membrane penetration, interaction with cell receptors, mechanisms of biological effects and approaches to clinical application. To reach this purpose a meta-synthesis literature review of 44 relevant scientific papers from Web of Science, Scopus, Pubmed databases was conducted.

\section{Stability of short peptide sequences.}

Stability of short sequence peptides, their interaction with cell receptors and mechanism of action in human body are one of the most disputable issues in oligopeptides biology. It is still questionable whether oligopeptides exert their biological effect as the entire sequence or after they are degraded to smaller peptides.

One of the advantages of oligopeptides, repeatedly reported in literature is the possibility of their oral administration since numerous low molecular weight peptides were shown to be resistant to gastrointestinal enzymes in contrast to polypeptides, known to be easily degraded and difficultly passing through the intestinal mucosa [2, 16-19]. Oral bioavailability is characteristic for the small peptide molecules with typical molecular weights of $<50$ Da, whereas larger 'biologics' typically $>5000$ Da need to be delivered via injection [20]. Namely, dipeptides were shown to penetrate biological barriers due to the presence of specific ATP-dependent transporters in enterocytes and blood-brain barrier [5].

According to literary data stability of short peptides is mediated by their structure and molecular weight [16-18, 20, 21]. Oligopeptides, containing more than 4 amino acids show a lower transport ability than di-/tripeptides, possibly due to the presence of paracellular tight junctions [16]. Some di-/ tripeptides were reported to be able to permeate through intestinal membranes in their intact forms via peptide transporter systems, while others are vulnerable to protease degradation [16]. Namely, some investigators report that alanine-, phenylalanine- and prolin-containing peptides as well as short peptides of the structure glycil-glycin, glycin-sarcosyl, carnosine can be absorbed into circulation from the gastrointestinal tract as entire molecules and even their excretion with urine was shown [22].

Studies of the tetrapeptide Lys-Glu-Asp-Ala showed that this compound was not hydrolyzed even by the peptidases of the small intestine and under the conditions in vitro it was hydrolyzed only for $50 \%$ [23]. As mentioned above, different glyprolines were reported to modulate the activity of gastrointestinal enzymes along with high stability to enzymatic hydrolysis [2, 21, 24-26]. The pentadecapeptide BPC 157 (Gly-Glu-Pro-Pro-Pro-Gly-Lys-Pro-Ala-AspAsp-Ala-Gly-Leu-Val) was also reported to be especially stable and in vitro studies showed that this compound was not broken down by gastric juice during a 24 hours period [27]. Two food-derived angiotensin converting enzyme inhibitory peptides, Ile-Pro-Pro and Leu-Lys-Pro were confirmed to be stable against intestinal and liver peptidases [28]. Oligopeptides of the structure Ser-Met, Asn-CysSer, glutathione and their zinc-peptide complexes were shown to be resistant to pepsin but not to pancreatin [16, 28]. Pancreatin was shown to hydrolyse partly Ser-Met, Asn-Cys-Ser and zinc-peptide complexes, but more than half of them remained in their original form after gastrointestinal digestion [16, 28, 29]. In vitro studies of the hydrolysis of 2 peptides 
of the structure Lys-Glu-Asp-Ala (livagen) and epithalon (Ala-Glu-Asp-Gly) in different parts of gastrointestinal tract showed that Lys-Glu-Asp-Ala was unsignificantly hydrolysed in stomach and both LysGlu-Asp-Ala and Ala-Glu-Asp-Gly were resistant to proteases of the proximal part of the small intestine and jejunum [22]. N-acyl derivatives of Pro-Gly-ProLeu proved to be resistant to the action of leucine aminopeptidase and other enzyme systems [25].

Another important issue, demanding deeper elucidation is the stability of short peptides in plasma. The hexapeptide Arg- $\alpha$-Asp-Lys-Val-Tyr-Arg was shown to be stable in in aqueous solutions, while in plasma it was rapidly bound by albumins [4]. A derivative of Arg-Gly-Asp-Trp-Arg, a new patented antithrombotic small peptide, with $\omega$-aminocaprylic acid on its N-terminus ( $\omega$ RWR) was shown to be stable in plasma [30]. Some glyprolines were shown to be active in plasma 60 and 90 min after the injection [31].

In peptide drugs engineering huge efforts are also devoted to stabilize peptides against proteases present in serum or plasma, therefore, peptide sequences of potent drug candidates are typically substituted to eliminate motifs recognized by proteases or to incorporate structural features preventing proteolysis [23]. Thus, binding of the tripeptide ProGly-Pro to C-terminals of unstable regulatory peptide taftsin solved the problem of its stabilisation and resulted in the creation of a new peptide anxiolytic drug (selank) [31].

By shortening the overall amino acid amount of somatostatin and replacing L:-analogue amino acids with D:-amino acids, plasma half life time of the derivate octreotide was 1.5 hours in comparison to only few minutes of somatostatin [22]. A PEG (2,40 K) conjugate of INF-alpha-2b exhibited a 330-fold prolonged plasma half life time compared to the native protein [22].

Certain oligopeptides of glyprolines structure were shown to cross blood-brain barrier [21].

\section{Cell penetration and molecular mechanisms of the interaction of short sequence peptides with cell receptors}

Pinocytosis was presumed to be the main mechanism how short sequences enter the cell [25]. For a long time it was unclear whether short peptides penetrate the cytoplasmic and nuclear membrane and then bind to DNA or they bind to receptors (intracellular or on cell membranes) and activate the intracel- lular signal cascades, which results in modification of the gene expression $[3,14]$. Assessing the molecular mechanism of action of the group of biologically active glyprolines in the central nervous system it was shown that biological activity of short peptide molecules is probably mediated by their specific ligand-receptor interaction on the plasma membranes of target cells and that these processes are complicated by the presence of active peptide proteolysis, which results in both changes in the concentration of molecules of the initial peptide and the occurrence of new peptides [21].

FITC-labeled di- and tripeptides were shown to penetrate into the cytoplasm, nuclei, and nucleoli of HeLa cells [1]. Since eukaryotic cell nucleus has a system of nuclear pores formed by protein complexes nucleoporins, whose inner diameter is about $50 \mathrm{~nm}$, nucleus is permeable for free diffusing low-molecular-weight substances with a molecular weight $\leq 3500 \mathrm{Da}$ [3]. Therefore, short peptides by their physical and chemical characteristics (charge, volume, and hydrophoby) can penetrate through the cytoplasmic and nuclear membranes of the cell, bind to complementary sequences in the gene promoters, which results in the synthesis of the relevant mRNA and triggering of the translation process $[3,15]$. The experiments with series of oligopeptides with particular physical and chemical properties based on the primary structure of $\beta$-catenin and C-reactive protein showed that these sequences inhibit vital genes involved in cell division in a plant model [14]. Such oligopeptides with regulating activity were called 'peptide-i' peptides, referring to their ability to interfere with the expression of particular genes, and thus with the expression of the related biological activities [15]. This data is supported by the studies of Khavinson group, who proposed that interaction with DNA is the key moment of the realization of the biological effect of the short peptides $[3,8,14$, 19]. This concept was supported by the data that the alterations in the peptidergic regulation of the body cause changes of the functional status of the cell, resulting in the decrease of certain genes expression and protein biosynthesis [2, 3, 12, 14, 15].

\section{The mechanism of action of short sequence peptides}

The direction of oligopeptides action in terms of specific genes expression depends on the peptide structure and concentration [12]. Active site of regulatory peptides and proteins interacting directly 
with the receptor molecule consists of the limited number of amino acid residues, amount of which is determined by the competition between precision of recognition and rate of peptide-receptor complex dissociation [5].

The effect of short peptide molecules on gene expression presents a great opportunity to use oligopeptides to treat human diseases, knowing that about $\sim 3,000$ human genes are disease-modifying genes and $\sim 3,000$ are druggable genes [17, 32].

It was established that low-weighing oligopeptides realize their effect on the cell, chromosomal, genome and molecular levels [2, 3, 12, 14]. Oligopeptides are also known to affect the activity of hormones and enzymes [2, 11, 22, 31]. It was also hypothesized that biological activity of short sequence peptides is associated with their prominent antioxidant properties, although this data is contradictory as some oligopeptides were reported to have prooxidant effect. A number of studies have demonstrated the effect of short peptides on the proliferation and differentiation of stem cells [14, 33]. Several oligopeptides were reported to exert potent geroprotective effect due to the inhibition of apoptosis, induction of telomerase activity and telomere elongation in human fibroblast culture, which can be due to reactivation of the telomerase gene in somatic cells and indicates the possibility of prolonging the life span of a cell population [33].

\section{Application of short peptide sequences in medicine}

Biological effects of short peptide sequences are very diverse dependently on their structure what makes them perspective candidates for therapeutic use in many fields of medicine, particularly in the light of personalized medicine [34]. Actually the peptide market is growing twice as quickly as the rest of the drug market and $\sim 80 \%$ of the peptide drug market is represented by small molecules [17]. Some short peptide sequences are already well known as registered official drugs, for instance, gastroprotective short sequence peptide drug dalargin (Tyr-DAla-Gly-Phe-Leu-Arg) [24], larger niche is still used as food supplements and numerous oligopeptides are being tested in preclinical research and in different stages of clinical trials.

The fields of the most perspective application of short peptide sequences in medicine cover dermatology, antimicrobial therapy, immunoregulation, regulation of functions of different organs and antitumor treatment, treatment of nervous system disorders, geroprotection, drugs delivery and use of oligopeptides as carriers for metals, cell culture.

Short sequence amino acids or oligopeptides represent a relatively new and promising area of dermatology and cosmetology, namely anti-wrinkle treatment [10]. Recent discoveries include peptides that stimulate extracellular matrix synthesis through either increasing fibroblast synthesis of collagen or decreasing collagen degradation [1].

Antimicrobial peptides have recently gathered significant attention as an emerging source of potential antibiotics, due to the swift emergence of multidrug-resistant bacteria and a dwindling antibiotic pipeline [35]. Since the vast majority of antimicrobial peptides are long, comprised of more than 10 amino acids, resulting in significant production costs for their synthesis while simultaneously displaying metabolic instability and relatively poor pharmacological profiles, efforts have been shifted to shorter molecules and the development of new peptidomimetic approaches [35].

Thymic peptides and their artificial short sequence derivatives for many decades have been marketed as immunomodulators, in particular Thymogen (L- $\alpha$-glutamil-L-tryptophan) and Thymohexin (Arg- $\alpha$-Asp-Lys-Val-Tyr-Arg) [4, 8]. The enhancement of innate and adaptive immune responses was reported in mice under the effect of walnut oligopeptides, including but not limited to boosting phagocytic capacity of macrophages, activating NK cells, improving cell-mediated and humoral immunities [29, 36].

Oligopeptides extracted from hen's egg yolks were reported to suppress the development of hypertension in spontaneously hypertensive rats, possibly by the inhibition of the angiotensin-converting enzyme [37]. Oligopeptides derived from soybean were suggested for possible use as natural antioxidants or antihypertensive compounds in the pharmaceutical and functional food industries, to be effective in pain control by increasing the absorption of opioids compared with a control mixture of proteins in healthy adults and had a significant impact on endurance performance [37].

BPC 157 (Gly-Glu-Pro-Pro-Pro-Gly-LysPro-Ala-Asp-Asp-Ala-Gly-Leu-Val), also known as Bepecin, PL 14736 and PL10 has demonstrated consistently positive and prompt healing effects for various injury types, both traumatic and systemic and for a plethora of soft tissues in different animal models [38]. 
Literary data provide increasing evidence on gastroprotective properties of numerous short sequences, in particular glycine-proline containing peptides, pentadecapeptide BPC 157 (Gly-Glu-ProPro-Pro-Gly-Lys-Pro-Ala-Asp-Asp-Ala-Gly-LeuVal), thymohexin (Arg- $\alpha$-Asp-Lys-Val-Tyr-Arg), walnut oligopeptides, met-enkephaline (His-DTrp-Ala-Trp-D-Phe-Lys-NH2) and leu-enkephaline (Tyr-Gly-Gly-Phe-Leu), demorphine (H-Tyr-D-AlaPhe-Gly-Tyr-Pro-Ser-NH2) and sedatine (H-ArgTyr-D-Ala-Phe-Gly-OH), H-Glu-Asp-Gly-OH and H-Lys-Glu-Asp-OH [2, 7-9, 39]. L-carnosine and dalargin (Tyr-D-Ala-Gly-Phe-Leu-Arg) for several decades have been registered in some countries as antiulcer remedies [2].

According to literary data, gastroprotective effects of short sequence opioid peptides are attributable in particular to their regulatory effects on stomach secretion and centrally induced gastroprotective effect of neuropeptides may be mediated by a vagal dependent increase of gastric mucosal resistance to injury, activation of vagal cholinergic pathway, resulting in the stimulation of the release of mucosal prostaglandins and nitric oxide [2].

The gastroprotective effect of glyprolines some authors explain by anti-inflammatory action of these substances, their involvement in the regulation of acid and bicarbonate secretion and ability to accumulate in the gastric mucosa with further involvement in the synthesis of the structural peptides, including collagen [2]. The studies of Falaleyeva T. et al showed that pronounced gastroprotective effects of the tripeptide Pro-Gly-Pro and its metabolite Gly-Pro on the models of water-immersion restraint stress and ethanol-induced gastric lesions in rats were largely determined by the antioxidant properties of these compounds [40, 41]. The decrease in the severity of ethanol-induced erosions and ulcer lesions after preventive treatment with Pro-Gly-Pro or Gly-Pro correlated with a decrease in the content of lipid peroxidation products to a control level, activities of superoxide dismutase and catalase also returned to control values [41].

Thymohexin (Arg- $\alpha$-Asp-Lys-Val-Tyr-Arg) was shown to decrease the area and damage index of epinephrine and indomethacin-induced gastric lesions in rats, that was accompanied by the decrease of inducible nitric oxide activity and thiobarbituric acid products content, thus also its antioxidant effect $[8,9,42]$.
In indomethacin-induced gastric lesions in rats a tripeptide H-Glu-Asp-Gly-OH was shown to affect the glycosylation procession in the rat gastric mucosa and to some extent to reverse glycosylation changes caused by cyclooxygenase-1/cyclooxygenase-2 inhibition with indomethacin [7].

In terms of antitumor effects a short 14 amino acid peptide (called RK1), purified from scorpion venom was shown to inhibit cell proliferation, migration and angiogenesis of U87 (Glioblastoma) and IGR39 (Melanoma), being the first natural peptide able to abolish completely the proliferation of cancer cells [43].

Selected oligopeptides (3 up to 7 amino acids) derived from the pregnancy hormone human chorionic gonadotropin were shown to inhibit severe inflammation, the onset of type I diabetes, renal failure and tumorigenesis [15]. And one of these oligopeptides (AQGV) has already been successfully tested in human Phase I and IIa studies [15].

Tryptophan-tyrosine and tryptophan-methionine peptides were shown to suppress the primary microglia activation and tryptophan-methionine was shown to supress inflammation in the brains of Alzheimer's disease model mice [44].

In terms of geroprotection peptide treatment reduced the incidence of cancer and prolonged the median and maximum lifespan in experimental animals $[3,14]$.

Small peptides are also supposed to be suitable for the modification of liposomes, being biocompatible, biodegradable, and less antigenic compared with antibody and other modifiers [41]. Literary data gives two examples of the use of liposomal oligopeptides: one for antimetastatic therapy and the other for antineovascular therapy [41].

Oligopeptides can also be used as carriers for metals, in particular Zn, for enhanced mineral bioavailability, it is crucial that metal-chelating peptides should be partially or fully resistant to the hydrolytic action of digestive enzymes [29].

Short peptides are also considered to be bioregulators in the maintenance of structural and functional homeostasis of cell populations in cell culture studies. AEDG and KED peptides were shown to prolong stem cell division in vitro and prevent its senescence and apoptosis, prevent p16 and p21 gene expression and protein synthesis, that allows their use as supplementary substances in culture media to delay the expression of senescence markers in long term stem cell culture [39]. 
Ta b le. Stability, cell penetration, mechanisms of biological effects and approaches to clinical and laboratory application of short sequence peptides

\begin{tabular}{|c|c|c|}
\hline $\begin{array}{c}\text { Characterisation } \\
\text { of short sequence } \\
\text { peptides }\end{array}$ & Data & Reference \\
\hline $\begin{array}{l}\text { Stability in } \\
\text { gastrointestinal tract }\end{array}$ & $\begin{array}{l}\text { Low molecular weight peptides }(<500 \text { Da) were shown to be } \\
\text { resistant to gastrointestinal enzymes and can be applied orally }\end{array}$ & $\begin{array}{l}{[2,5,16-19} \\
23,27,28]\end{array}$ \\
\hline $\begin{array}{l}\text { Stability in } \\
\text { blood plasma }\end{array}$ & $\begin{array}{l}\text { Some short peptide sequences, namely glyprolines, were shown } \\
\text { to be stable in plasma } 60 \text { and } 90 \text { minutes after the injection, } \\
\text { whereas the others are rapidly degraded by plasma proteases or } \\
\text { bound by albumins (f.i. Arg- } \alpha \text {-Asp-Lys-Val-Tyr-Arg) }\end{array}$ & {$[22,30,31]$} \\
\hline \multirow[t]{2}{*}{ Blood brain barrier } & $\begin{array}{l}\text { Dipeptides were shown to penetrate blood-brain barrier due to } \\
\text { the presence of specific ATP-dependent transporters }\end{array}$ & [5] \\
\hline & Some glyprolines were shown to cross blood-brain barrier. & [21] \\
\hline \multirow[t]{2}{*}{$\begin{array}{l}\text { Mechanism of } \\
\text { cell penetration }\end{array}$} & $\begin{array}{l}\text { Pinocytosis was presumed to be the main mechanism how short } \\
\text { sequences enter the cell }\end{array}$ & [25] \\
\hline & $\begin{array}{l}\text { Biological activity of some short peptide sequences is mediated } \\
\text { by their specific ligand-receptor interaction on the plasma } \\
\text { membranes }\end{array}$ & [21] \\
\hline \multirow[t]{4}{*}{ Mechanism of action } & $\begin{array}{l}\text { Short peptides can penetrate both the cytoplasm and nucleus, } \\
\text { bind to complementary sequences in the gene promoters, } \\
\text { affecting the processes of transcription and translation }\end{array}$ & $\begin{array}{c}{[1,3,14,15} \\
19,32]\end{array}$ \\
\hline & $\begin{array}{l}\text { Low-weighing oligopeptides realize their effect on the cell, } \\
\text { genome and molecular levels }\end{array}$ & {$[2,3,12,14]$} \\
\hline & Oligopeptides affect the activity of hormones and enzymes & {$[2,11,22,31]$} \\
\hline & Oligopeptides regulate oxidation/antioxidation balance & {$[8,9,34]$} \\
\hline \multirow[t]{10}{*}{ Fields of application } & Antimicrobial treatment & [36] \\
\hline & Dermatology and cosmetology & {$[1,10]$} \\
\hline & Modulation of immune function & {$[8,9,37]$} \\
\hline & Antihypertension treatment & {$[11,28]$} \\
\hline & Increase of antioxidant defense & {$[8,9,29]$} \\
\hline & Gastroprotection & $\begin{array}{l}{[2,7-9,24} \\
27,39,42]\end{array}$ \\
\hline & Antitumor therapy & {$[41,42]$} \\
\hline & Geroprotection & {$[3,14]$} \\
\hline & Drug delivery and use as carries for metals & {$[41,42]$} \\
\hline & Cell culture & [34] \\
\hline \multirow[t]{4}{*}{$\begin{array}{l}\text { Directions for } \\
\text { future research }\end{array}$} & Pharmacotherapy & $\begin{array}{l}{[1,2,7,10,11} \\
20,35-38]\end{array}$ \\
\hline & Drug delivery & {$[41,42]$} \\
\hline & Cell culture & [34] \\
\hline & $\begin{array}{l}\text { Stabilisation of short sequence peptides (elimination of motifs } \\
\text { recognized by proteases, shortening the overall amino acid } \\
\text { amount, replacing of relevant amino acids, conjugation with } \\
\text { other molecules) }\end{array}$ & {$[22,23,32,33]$} \\
\hline
\end{tabular}




\section{Conclusions and future prospects}

Given the diverse biological effects of short sequences, their low immunogenicity, lack of toxicity and opportunities to generate various peptide analogues through specific amino acid substitutions and alterations, oligopeptides are promising candidates to occupy a wider niche in pharmacotherapy as well as for cell cultures and drug delivery purposes.

Conflict of interest. Authors have completed the Unified Conflicts of Interest form at http://ukrbiochemjournal.org/wp-content/uploads/2018/12/ coi_disclosure.pdf and declare no conflict of interest.

Funding. The manuscript was written in the framework of the planned research work of the Department of Biochemistry of Danylo Halytsky Lviv National Medical University "Peculiarities of the pathogenesis, diagnosis and treatment of the diseases of cardiovascular, digestive, endocrine and respiratory system in clinic and experiment.

\section{КОРОТКОЛАНЦЮГОВІ ПЕПТИДИ: СУЧАСНІ ЗНАННЯ ТА ПЕРСПЕКТИВИ}

\section{X. М. Насадюк}

\author{
Львівський національний медичний \\ університет імені Данила Галицького, \\ кафедра біохімії, Україна; \\ e-mail: nasadyukch@gmail.com
}

Згідно 3 сучасними уявленнями, біологічні ефекти багатьох пептидів обумовлені їх коротколанцюговими фрагментами - олігопептидами, що містять від 2 до 20 амінокислот, i активність коротких пептидів часто значно перевищує таку протеїнів-попередників. Метою огляду було узагальнити сучасні дані щодо стабільності коротколанцюгових пептидів, механізмів проникнення їх у клітину, взаємодії 3 клітинними рецепторами, біологічних ефектів та підходів до клінічного використання. Стабільність коротколанцюгових пептидів обумовлена їх структурою та молекулярною масою. Повідомлялося, що деякі ди-/трипептиди здатні всмоктуватися через слизову оболонку кишечника в інтактній формі завдяки участі пептидних транспортних систем, тоді коли інші піддаються розпаду протеазами. Хоча припускається, що піноцитоз $є$ основним механізмом проникнення олігопептидів у клітину, показано, що деякі ліпофільні олігопептиди пенетрують у клітинну мембрану за таким самим механізмом як стероїдні чи тироїдні гормони. Також описано їх специфічні внутрішньоклітинні рецептори. Олігопептиди 3 низькою молекулярною масою реалізують свою дію на клітинному, хромосомному, геномному та молекулярному рівнях. Перевагами коротколанцюгових пептидів $\epsilon$ можливість перорального застосування (для низькомолекулярних сполук), низька імуногенність, високі тканинна специфічність i біологічний ефект, економічність та екологічність їх синтезу. Отже, коротколанцюгові пептиди можуть розглядатись як перспективні сполуки для фармакотерапії, клітинного культивування та векторної доставки лікарських засобів.

К л ю ч о в і с лов а: коротколанцюгові пептиди, олігопептиди, пептидергічна регуляція, протеоміка.

\section{References}

1. Reddy BY, Jow T, Hantash BM. Bioactive oligopeptides in dermatology: Part II. Exp Dermatol. 2012; 21(8): 569-575.

2. Nasadyuk C, Sklyarov A. Gastroprotective oligopeptides. Gastroenterol Hepatol Open Access. 2015; 3(1): 210-214.

3. Khavinson VKh, Lin'kova NS, Tarnovskaya SI. Short Peptides Regulate Gene Expression. Bull Exp Biol Med. 2016; 162(2): 288-292.

4. Sawicka J, Dzierżyńska M, Wardowska A, Deptuła M, Rogujski P, Sosnowski P, Filipowicz N, Mieczkowska A, Sass P, Pawlik A, Hać A, Schumacher A, Gucwa M, Karska N, Kamińska J, Płatek R, Mazuryk J, Zieliński J, Kondej K, Młynarz P, Mucha P, Skowron P, Janus Ł, Herman-Antosiewicz A, Sachadyn P, Czupryn A, Piotrowski A, Pikuła M, Rodziewicz-Motowidło S. Imunofan-RDKVYR peptide-stimulates skin cell proliferation and promotes tissue repair. Molecules. 2020; 25(12): 2884.

5. Gudasheva TA, Ostrovskaya RU, Seredenin SB. Novel technologies for dipeptide drugs design and their implantation. Curr Pharm Des. 2018; 24(26): 3020-3027.

6. Kapica M, Laubitz D, Puzio I, Jankowska A, Zabielski R. The ghrelin pentapeptide inhibits 
the secretion of pancreatic juice in rats. $J$ Physiol Pharmacol. 2006; 57(4): 691-700.

7. Nasadyuk CM, Sogomonyan.A, Yashchenko AM, Sklyarov AY. Lectinocytochemical study of rat stomach mucosa under the conditions of cyclooxygenase-1/-2 blockage and pretreatment with H-Glu-Asp-Gly-OH. Ukr Biochem J. 2020; 92(2): 33-43.

8. Nasadyuk C, Sklyarov A. Thymohexin exhibits cytoprotective effect in experimental gastric lesions in rats both through the inhibition of inducible nitric oxide synthase and reduction of oxidative mucosal damage. Regul Pept. 2013; 180: 50-57.

9. Nasadyuk KH, Sklyarov OY. The influence of the short peptide of arg-alfa-asp-lys-val-tyrarg on the activity of NO-synthase system and processes of lipoperoxidation in experimental gastric lesions in rats. Annales Universitatis Mariae Curie-Sklodowska, Sectio DDD: Pharmacia. 2010; 23(3): 241-245.

10. Reddy B, Jow T, Hantash BM. Bioactive oligopeptides in dermatology: Part I. Exp Dermatol. 2012; 21(8): 563-568.

11. Kodama RT, Cajado-Carvalho D, Kuniyoshi AK, Kitano ES, Tashima AK, Barna BF, Takakura AC, Serrano SMT, Dias-Da-Silva W, Tambourgi DV, Portaro FV. New prolinerich oligopeptides from the venom of African adders: Insights into the hypotensive effect of the venoms. Biochim Biophys Acta. 2015; 1850(6): 1180-1187.

12. Khavinson V, Linkova N, Diatlova A, Trofimova S. Peptide regulation of cell differentiation. Stem Cell Rev Rep. 2020; 16(1): 118-125.

13. Zamyatnin AA. Structural-functional diversity of the natural oligopeptides. Prog Biophys Mol Biol. 2018; 133: 1-8.

14. Caputi S, Trubiani O, Sinjari B, Trofimova S, Diomede F, Linkova N, Diatlova A, Khavinson V. Effect of short peptides on neuronal differentiation of stem cells. Int J Immunopathol Pharmacol. 2019; 33: 2058738419828613.

15. Khan NA, Benner R. Human chorionic gonadotropin: a model molecule for oligopeptidebased drug discovery. Endocr Metab Immune Disord Drug Targets. 2011; 11(1): 32-53.

16. Shen W, Matsui T. Current knowledge of intestinal absorption of bioactive peptides. Food Funct. 2017; 8(12): 4306-4314.
17. Di L. Strategic approaches to optimizing peptide ADME properties. AAPS J. 2015; 17(1): 134-143.

18. Sun L. Peptide-Based Drug Development. Mod Chem Appl. 2013; 1(1): 1000e103.

19. Timofeeva NM, Khavinson VKh, Malinin VV, Nikitina AA, Egorova VV. Effect of peptide Livagen on activity of digestive enzymes in gastrointestinal tract and non-digestive organs in rats of different ages. Adv Gerontol. 2005; 16: 92-96. (In Russian).

20. Craik DJ, Fairlie DP, Liras S, Price D. The future of peptide-based drugs. Chem Biol Drug Des. 2013; 81(1): 136-147.

21. V'yunova TV, Andreeva LA, Shevchenko KV, Shevchenko VP, Myasoedov NF. The synthesis and study of simple glyprolines. Neurochem $J$. 2016; 10(3): 219-225.

22. Werle M, Bernkop-Schnürch A. Strategies to improve plasma half life time of peptide and protein drugs. Amino Acids. 2006; 30(4): 351367.

23. Böttger R, Hoffmann R, Knappe D. Differential stability of therapeutic peptides with different proteolytic cleavage sites in blood, plasma and serum. PLoS One. 2017; 12(6): e0178943.

24. Tolstenok IV, Fleyshman, Slobodenyuk EV. The impact of glyprolines on processes of ulceration in the experiment. Pacific Med J. 2016; (4): 1415. (In Russian).

25. Shevchenko KV, Bezuglov VV, Akimov MG, Nagaev IYu, Shevchenko VP, Myasoedov NF. Synthesis of N-acyl derivatives of Pro-Gly-ProLeu peptide: Proteolytic stability in vitro and effects on mouse macrophage cells RAW264.7. Dokl Biochem Biophys. 2017; 476(1): 333-336.

26. Misiura M, Miltyk W. Proline-containing peptides-New insight and implications: A Review. Biofactors. 2019; 45(6): 857-866.

27. Sikiric P, Seiwerth S, Rucman R, Turkovic B, Rokotov DS, Brcic L, Sever M, Klicek R, Radic B, Drmic D, Ilic S, Kolenc D, Vrcic H, Sebecic B. Stable gastric pentadecapeptide BPC 157: novel therapy in gastrointestinal tract. Curr Pharm Des. 2011; 17(16): 1612-1632.

28. Gleeson JP, Heade J, Ryan SM, Brayden DJ. Stability, toxicity and intestinal permeation enhancement of two food-derived antihypertensive tripeptides, Ile-Pro-Pro and LeuLys-Pro. Peptides. 2015; 71: 1-7.

29. Wang C, Li B, Wang B, Xie N. Degradation and antioxidant activities of peptides and zinc- 
peptide complexes during in vitro gastrointestinal digestion. Food Chem. 2015; 173: 733-740.

30. Yang L, Zhang L, Yan L, Zheng H, Lu P, Chen J, Dai J, Sun H, Xu Y, Yang T. Stability assessment of a new antithrombotic small peptide, Arg-GlyAsp-Trp-Arg (RGDWR), and its derivative. Biotechnol Lett. 2017; 39(8): 1183-1190.

31. Tomova TA, Prosekina EJu, Gridneva VI, Zamoshchina TA. The modulation of cholinergic influences on gastric secretory activity by peptides prolilglycilprolin and glycilprolin. Ann Tomsk State Univ Biol. 2011; (4(16)): 146-156. (In Russian).

32. Teleshova ES, Bochkarev VK, Syunyakov TS, Bugaeva TP, Neznamov GG. The results of clinical and EEG study of anxiolythic effects of heptapeptide selanc. Psychiatry. 2010; (4(46)): 26-35. (In Russian).

33. Wang T, Zhang YR, Liu XH, Ge S, Zhu YS. Strategy for the biosynthesis of short oligopeptides: green and sustainable chemistry. Biomolecules. 2019; 9(11): 733.

34. Sinjari B, Diomede F, Khavinson V, Mironova E, Linkova N, Trofimova S, Trubiani O, Caputi S. Short Peptides Protect Oral Stem Cells from Ageing. Stem Cell Rev Rep. 2020; 16(1): 159-166.

35. Nasadyuk CM, Sklyarov OYa. Personalized medicine: current status and prospects. Cell Organ Transplantol. 2019; 7(1): 63-65.

36. Domalaon R, Zhanel GG, Schweizer F. Short Antimicrobial Peptides and Peptide Scaffolds as Promising Antibacterial Agents. Curr Top Med Chem. 2016; 16(11): 1217-1230.

37. Mao R, Wu L, Zhu N, Liu X, Haj Y, Liu R, Du W, $\mathrm{Li}$ Y. Immunomodulatory effects of walnut (Juglans regia L.) oligopeptides on innate and adaptive immune responses in mice. $J$ Funct Foods. 2020; 73: 104068.
38. Zheng ZQ, Geng ZH, Liu JX, Guo ST. Compressed food with added functional oligopeptides improves performance during military endurance training. Asia Pac J Clin Nutr. 2017; 26(6): 1066-1075.

39. Gwyer D, Wragg NM, Wilson SL. Gastric pentadecapeptide body protection compound BPC 157 and its role in accelerating musculoskeletal soft tissue healing. Cell Tissue Res. 2019; 377(2): 153-159.

40. Falalyeyeva TM, Samonina GE, Beregovaya TV, Andreeva LA, Dvorshchenko EV. Effect of glyprolines on homeostasis of gastric mucosa in rats with stress ulcers. Bull Exp Biol Med. 2010; 149(1): 26-28.

41. Falalyeyeva TM, Samonina GE, Beregovaya TV, Andreeva LA, Dvorshchenko EA. Effect of glyprolines PGP, GP, and PG on homeostasis of gastric mucosa in rats with experimental ethanol-induced gastric ulcers. Bull Exp Biol Med. 2010; 149(6): 699-701.

42. Nasadyuk C, Panasyuk N, Fomenko I, Sklyarov O. The role of cyclooxygenase isoforms in the mechanisms of cytoprotection of gastric mucosa under the influence of hexapeptide Arga-Asp-Lys-Val-Tyr-Arg. Curr Issues Pharm Med Sci. 2012; 25(4): 446-448.

43. Khamessi O, Ben Mabrouk H, ElFessiMagouri R, Kharrat R. RK1, the first very short peptide from Buthus occitanus tunetanus inhibits tumor cell migration, proliferation and angiogenesis. Biochem Biophys Res Commun. 2018; 499(1): 1-7.

44. Ano Y, Yoshino Y, Uchida K, Nakayama H. Preventive effects of tryptophan-methionine dipeptide on neural inflammation and Alzheimer's pathology. Int J Mol Sci. 2019; 20(13): 3206. 